\title{
EVALUASI PELAKSANAAN PENDAFTARAN TANAH SISTEMASTIS LENGKAP DI KECAMATAN TUMPAAN KABUPATEN MINAHASA SELATAN
}

\author{
Peggye Lenda Olivia Rembeth \\ Bobby Jhon Vian Polii \\ Leonardus Ricky Rengkung
}

\begin{tabular}{ll}
\hline Naskah diterima melalui Email agrisosioekonomi@unsrat.ac.id & : Kamis, 22 Oktober 2020 \\
Disetujui diterbitkan & : Selasa, 27 Oktober 2020 \\
\hline
\end{tabular}

\begin{abstract}
This study aims to determine the evaluation of the complete systematic land registration program (PTSL) in Tumpaan District, South Minahasa Regency. The research was conducted from February to June 2020. The data sources in this study used primary and secondary data. Primary data is through direct interviews with implementers and participants. The number of respondents was 4 authorized officers and 21 participants in complete systematic land registration in 2017. Secondary data is data obtained through related agencies in this study. The data analysis used in this research is descriptive qualitative analysis. The results showed that the Complete Systematic Land Registration Activity in Tumpaan District, South Minahasa Regency has been running according to the activity stages. There were 18 or $85.71 \%$ of respondents who considered the implementation of PTSL activities in the good category, while 3 people or $14.28 \%$ considered it very good. The response to the counseling carried out by the National Land Agency Office of South Minahasa Regency, there were 2 people or $9.52 \%$ of respondents who said they did not understand the counseling delivered, while 19 respondents or as much as $90.47 \%$ said they understood the counseling about PTSL that was delivered. There were 7 people or $33.33 \%$ of the total respondents who felt very profitable about the existence of this PTSL program while 14 people or $66.66 \%$ of respondents felt the PTSL program was for them. 10 respondents or $47.61 \%$ of the total respondents did not experience difficulties in the process of managing PTSL, while 11 respondents or $52.38 \%$ had difficulties where the completeness of the files and data they had did not meet the requirements. ${ }^{*}$ prm*
\end{abstract}

Keywords: complete systematic land registration program (PTSL), evaluation

\begin{abstract}
ABSTRAK
Penelitian ini bertujuan untuk mengetahui evaluasi program pendaftaran tanah sistematik lengkap (PTSL) di Kecamatan Tumpaan Kabupaten Minahasa Selatan. Penelitian dilaksanakan pada bulan Februari sampai dengan Juni 2020. Sumber data dalam penelitian ini mengunakan data primer dan sekunder. Data primer yaitu melalui wawancara langsung dengan pelaksana dan peserta. Jumlah responden sebanyak 4 orang petugas yang berwenang dan 21 peserta pendaftaran tanah sistematis lengkap tahun 2017. Data sekunder yaitu data yang didapat melalui instansi yang terkait dalam penelitian ini. Analisis data yang digunakan dalam penelitian ini adalah analisis deskriptif kualitatif. Hasil penelitian menunjukkan bahwa kegiatan pendaftaran tanah sistematis lengkap di Kecamatan Tumpaan Kabupaten Minahasa Selatan telah berjalan sesuai dengan tahapan kegiatan. terdapat sebanyak 18 atau $85,71 \%$ responden yang menganggap pelaksanaan kegiatan PTSL berada pada kategori baik sedangkan 3 orang atau sebesar 14,28\% menganggap sangat baik. Respon terhadap penyuluhan yang dilaksanakan oleh Kantor Badan Pertanahan Nasional Kabupaten Minahasa Selatan terdapat 2 orang atau 9,52\% responden yang mengatakan belum paham dengan penyuluhan yang disampaikan, sedangkan 19 orang reponden atau sebanyak 90,47\% mengatakan paham dengan penyuluhan tentang PTSL yang disampaikan. Terdapat 7 orang atau 33,33\% dari total responden yang yang merasa sangat menguntungkan tentang adanya program PTSL ini sedangkan 14 orang atau 66,66\% responden merasa program PTSL menguntukan bagi mereka. 10 orang responden atau $47,61 \%$ dari total responden tidak mengalami kesulitan dalam proses pengurusan PTSL, sedangkan 11 orang responden atau sebanyak 52,38\% mendapatkan kesulitan dimana kelengkapan berkas dan data yang mereka miliki tidak memenuhi syarat. ${ }^{*}$ eprm*
\end{abstract}

Kata kunci : program pendaftaran tanah sistematik lengkap (PTSL), evaluasi 


\section{PENDAHULUAN}

\section{Latar Belakang}

Persoalan hak tanah sampai sekarang masih menjadi persoalan yang serius bagi pemerintah. Guna penyelesaiannya ditetapkanlah kebijakan pemerintah mengenai reformasi agraria sebagai bagian dari Nawa Cita Pemerintahan Presiden Joko Widodo dan Jusuf Kalla. Pada tataran operasional reformasi agrariaini dilakukan untuk melegitimasi aset tanah bagi masyarakat dan penataan akses masyarakat terhadap sumber-sumber ekonomi dan politik yang memungkinkan warga masyarakat memanfaatkan tanah secara baik.

Kegiatan pendaftaran atas tanah merupakan suatu proses yang dilakukan masyarakat untuk memperoleh sertipikat hak atas tanah. Sertipikat ini merupakan bukti kepemilikan paling kuat bagi pemilik tanah yang berfungsi untuk menjamin kepastian hukum. Idealnya semua bidang tanah di Indonesia harus bersertipikat. Berdasarkan Buku Realisasi Kegiatan Legalitas Aset dan Redristribusi Tanah Tahun 2015 - 2017 dari Badan Pertanahan Nasional sampai dengan Agustus 2017 pemerintah telah menyerahkan 2.889.993 sertipikat tanah. Di tahun 2018 pemerintah meningkatkan target menjadi 7 juta dan tahun 2019 target ditingkatkan menjadi 9 juta sertipikat.

Percepatan Pelaksanaan Pendaftaran Tanah Sistematis Lengkap diberlakukan di seluruh wilayah termasuk di Kabupaten Minahasa Selatan Provinsi Sulawesi Utara. Kabupaten Minahasa Selatan dengan luas wilayah sekitar 1.484,47 $\mathrm{km}^{2}$ terbagi dalam 17 kecamatan, penduduk 208.013 jiwa di 181 desa. Berdasarkan informasi awal dalam pelaksanaan Pendaftaran Tanah Sistematis Lengkap sejak tahun 2017 dari 17 kecamatan yang ada, Kecamatan Tumpaan merupakan kecamatan yang memiliki kasus pertanahan yang cukup berbeda dibandingkan dengan kecamatan lainnya. Program Pelaksanaan Pendaftaran Tanah Sistematis Lengkap yang dilaksanakan oleh Kantor Badan Pertanahan Kabupaten Minahasa Selatan melalui satuan tugas yuridis yang dibentuk telah melaksanakan program PTSL mulai dari persiapan melalui sosialisasi dan penyuluhan kepada pemerintah desa dan kecamatan, melibatkan masyarakat. Akan tetapi dalam pengumpulan data yuridis, pengukuran, pembuktian hak sampai dengan pemeriksaan tanah banyak mengalami kendala. Hal ini banyak disebabkan oleh status kepemilikan tanah yang bermasalah. Disamping itu juga masyarakat banyak yang kurang kooperatif dalam memenuhi persyaratan yang di wajibkan untuk dipenuhi. Pada situasi yang demikian menjadikan pelaksanaan program PTSL mengalami kendala.
Kecamatan Tumpaan yang memiliki luas wilayah $78,26 \mathrm{~km}^{2}$ dimana 2.805 bidang tanah telah disertipikat. Sementara dalam Pelaksanaan Program Pendaftaran Tanah Sistematis Lengkap tahun 2017 mendapatkan target 1.700 bidang tanah yang harus disertipikat di Kabupaten Minahasa Selatan, 418 khusus untuk Kecamatan Tumpaan dengan perincian desa Lelema sebanyak 24 bidang, desa Matani sebanyak 43 bidang, desa Matani 1 sebanyak 30 bidang, desa Munte sebanyak 85 bidang, desa Popontolen sebanyak 90 bidang, desa Tangkunei sebanyak 56 bidang, desa Tumpaan Baru sebanyak 42 bidang, desa Tumpaan Dua sebanyak 24 bidang dan desa Tumpaan Satu sebanyak 24 bidang.

Penelitian evaluasi program pelaksanaan pendaftaran tanah sistematik lengkap (PTSL) ini dilakukan untuk mendapatkan penilaian mengenai cakupan efektivitas, efisiensi, kesamaan / kesesuaian, responsivitas maupun ketepatan pembuatan sertipikat tanah. Efektivitas berkaitan dengan pencapaian pelaksanaan program pendaftaran tanah sistematik lengkap dengan bercermin pada tujuan kebijakan yang ada. Demikian pula halnya dengan efisiensi dalam penggunaan sumber daya sehingga program ini dapat terlaksana. Pada aspek kesesuaian/kecukupan dalam kaitannya dengan terget yang diberikan dibandingkan dengan kebutuhan masyarakat serta jumlah bidang tanah yang berlum disertipikasi, demikian pula halnya dengan responsivitas dari pelaksana yuridiksi atas keluhan maupun kelemahan yang dimiliki leh masyarakat sehubungan dengan permasalahan status tanah yang dimiliki sehingga ketepatan dan keabsahan sertipikat yang diterima oleh masyarakat dapat dipertangungjawabkan.

Hasil dari evaluasi kegiatan ini menjadi bagian yang penting bagi pemerintah guna membangun wilayah yang dapat mendukung program pemerintah pada sektor reformasi agraria. Berdasarkan uraian diatas maka penting untuk melakukan penelitian dengan judul: Evaluasi Pelaksanaan Pendaftaran Tanah Sistematis Lengkap di Kecamatan Tumpaan Kabupaten Minahasa Selatan".

\section{Rumusan Masalah}

Perumusan masalah dalam penelitian ini yaitu bagaimana evaluasi pelaksanaan kegiatan Pendaftaran Tanah Sistematis Lengkap di Kecamatan Tumpaan Kabupaten Minahasa Selatan?

\section{Tujuan Penelitian}

Penelitian ini dilakukan untuk mengevaluasi program pendaftaran tanah sistematik lengkap (PTSL) di Kecamatan Tumpaan Kabupaten Minahasa Selatan. 


\section{Manfaat Penelitian}

Penelitian ini diharapkan dapat memberikan manfaat baik secara teoritas maupun secara praktis yaitu :

1. Manfaat Teoritis, hasil penelitian ini diharapkan dapat memberikan manfaat dalam pengembangan keilmuan perencanaan pembangunan wilayah khususnya dalam bidang pembangunan. Serta dapat dijadikan referensi dalam pengkajian penelitian serupa untuk peneliti lainnya.

2. Manfaat Praktis, hasil penelitian ini diharapkan dapat menjadi bahan rekomendasi Pemerintah termasuk Kantor Pertanahan dalam perbaikan program pelaksanaan pendaftaran tanah sistematik lengkap serta dalam menyelesaikan masalah pertanahan.

\section{METODE PENELITIAN}

\section{Tempat dan Waktu Penelitian}

Penelitian ini dilakukan pada bulan Februari sampai dengan Juni 2020. Berlokasi di Kecamatan Tumpaan Kabupaten Minahasa Selatan dengan dasar pertimbangan bahwa pelaksanaan Pendaftaran Tanah Sistem Lengkap telah dilakukan oleh Kantor Pertanahan Kabupaten Minahasa Selatan tahun 2017 di Kecamatan Tumpaan. Pada tataran pelaksanaan di Kecamatan Tumpaan banyak ditemukan masalah mulai dari persiapan/sosialisasi, pengukuran tanah, pemeriksaan tanah dan pengumuman yang merupakan kendala yang dihadapi oleh satuan tugas yang dibentuk. Akan tetapi dilihat dari realisasi dapat mencapai 418 bidang tanah yang dilakukan Pendaftaran Tanah Sistem Lengkap. Selain itu, Kecamatan Tumpaan juga merupakan kecamatan yang tanahnya dapat disertipikatkan sebanyak 2.805 bidang melalui semua program. Keadaan ini sangat berbeda dengan kecamatan lainnya di Kabupaten Minahasa Selatan baik dalam hal realisasi program maupun dalam penerbitan sertipikat.

\section{Jenis Penelitian}

Jenis penelitian ini adalah deskriptif dengan pendekatan kualitatif. Pendekatan kualitatif digunakan untuk mengungkapkan secara komprehensif dan alami bagaimana evaluasi program Pendaftaran Tanah Sistem Lengkap di Kecamatan Tumpaan Kabupaten Minahasa Selatan. Selanjutnya metode analisis deskriptif digunakan untuk menemukan fakta dengan interpretasi dan melukiskan secara akurat sifat dari beberapa fenomena kelompok atau individu yang berasal dari hasil penemuan sebagaimana yang menjadi objek permasalahan (Creswell, 2002).
Penggunaan pendekatan kualitatif dan metode deskriptif dalam penelitian ini adalah untuk mengkaji secara kualitatif dan mendeskripsikan, bagaimana persepsi dan pemaknaan tentang evaluasi evaluasi program Pendaftaran Tanah Sistem Lengkap di Kecamatan Tumpaan Kabupaten Minahasa Selatan dan menemukan fakta-fakta dalam evaluasi program Pendaftaran Tanah Sistem Lengkap di Kecamatan Tumpaan Kabupaten Minahasa Selatan tersebut. Seluruh data diperoleh secara langsung dari informan di lapangan dengan menggunakan wawancara dan observasi.

Melalui pendekatan kualitatif, penelitian tentang evaluasi program Pendaftaran Tanah Sistem Lengkap di Kecamatan Tumpaan Kabupaten Minahasa Selatan akan mampu memberikan informasi yang akurat sehingga sangat membantu proses interpretasi informasi dan data yang diperoleh. Aktivitas penelitian ini dicirikan oleh kegiatan mengumpulkan, menggambarkan, dan menafsirkan data tentang situasi yang dialami, hubungan tertentu, kegiatan, pandangan, sikap yang ditunjukkan atau tentang kecenderungan yang tampak dalam proses yang berlangsung, pertentangan yang meruncing serta kerjasama yang dijalankan. Melalui desain ini pula dapat diperoleh gambaran fenomena dan fakta tentang Evaluasi Program Pelaksanaan Pendaftaran Tanah Sistem Lengkap di Kecamatan Tumpaan Kabupaten Minahasa Selatan secara utuh.

\section{Teknik Pengambilan Sampel dan Penentuan Informan}

Penentuan informan dilakukan dengan menggunakan teknik Purposive sampling dimana jumlah informan ditentukan oleh peneliti berdasarkan pertimbangan tertentu. Informan dalam penelitian ini merupakan seorang yang mengerti dan pahan secara mendalam tentang obyek penelitian dan persoalan atau permasalahan yang ada dan darinya dapat diperoleh informasi yang akurat dan terpercaya baik berupa pernyataan, keterangan atau data - data yang dapat membantu dalam memenuhi kebutuhan peneliti dalam menggali informasi terkait dengan obyek penelitian yang sedang diteliti. Oleh sebab itu dalam mengumpulkan data dilapangan peneliti harus mengetahui informan-informan yang sesuai dan tahu tentang obyek penelitian yang diteliti secara mendalam guna mendapatkan hasil yang akurat. Kriteria menentukan informan menurut Sugiyono (2011) antara lain sebagai berikut:

1. Orang yang mampu memahami suatu masalah yang diteliti dengan proses enkulturisasi yaitu proses penghayatan bukan sekedar mengetahui.

2. Orang yang masih berkecimpung dalam masalah yang diteliti.

3. Orang yang memiliki waktu memadai untuk dimintai informasi. 
4. Orang yang mampu menyampaikan informasi secara lebih obyektif bukan berdasarkan subyektivitas.

5. Orang yang masih baru dikenal oleh peneliti sehingga peneliti dapat menjadikannya sebagai narasumber penelitian.

Informan dalam penelitian ini dilakukan dengan purposive sampling. Informan di dapat melalui informasi dari orang - orang yang terlibat langsung dalam proses pelayanan yang terdiri dari pelaksana dan peserta, yaitu sebagai berikut:

a. Kepala Kantor Pertanahan Kabupaten Minahasa Selatan.

b. Kepala Seksi Hubungan Hukum Pertanahan Kabupaten Minahasa Selatan.

c. Kepala Seksi Infrastruktur Pertanahan Kabupaten Minahasa Selatan.

d. Hukum Tua Desa Munte Kecamatan Tumpaan.

e. 21 Peserta Pendaftaran Tanah Sistematis Lengkap Tahun 2017 di Kecamatan Tumpaan yang bersedia menjadi narasumber atau responden penelitian.

\section{Konsep Pengukuran Variabel}

Variabel-variabel yang di ukur dalam penelitian ini terdiri dari :

1) Pendaftaran Tanah Sistematis Lengkap

Kegiatan pendaftaran tanah untuk pertama kali yang dilakukan secara serentak yang meliputi semua obyek pendaftaran tanah yang belum didaftar dalam satu wilayah desa atau kelurahan atau nama lainnya yang setingkat dengan itu. Kegiatan PTSL diukur lewat efektivitas antara rencana dan realisasi serta jumlah bidang yang terdaftar dalam suatu lokasi penetapan.

2) Pengembangan wilayah

Kegiatan PTSL merupakan salah satu program pembangunan dibidang pertanahan, dimana salah satu isu strategis yang diusung dalam pembangunan pertanahan yaitu pembangunan yang berkaitan dengan unsur tata ruang dan lokasi kegiatan ekonomi dan sosial secara terintegrasi. Ketersediaan tanah merupakan salah satu faktor yang penting dalam memulai kegiatan pembangunan bagi kepentingan umum.

\section{Observasi}

\section{Teknik Pengumpulan Data}

Observasi merupakan suatu pengamatan secara mendalam terhadap objek penelitian yaitu dengan mendatangi wilayah Kecamatan Tumpaan Kabupaten Minahasa Selatan yang merupakan lokasi penelitian untuk mengamati secara langsung bagaimana keadaan objek penelitian.

2. Kuesioner

Kuesioner merupakan kegiatan memberikan daftar pertanyaan kepada responden yang terkait dengan kepemilikan tanah absentee/guntai untuk menggali informasi yang diperlukan.

\section{Wawancara Mendalam (In-Depth Interview)}

Peneliti menggunakan teknik wawancara mendalam (In-depth Interview) untuk melakukan pengumpulan data. Wawancara mendalam merupa-kan suatu percakapan yang diarahkan pada suatu persoalan tertentu, kegiatan ini merupakan proses tanyajawab lisan di mana dua orang atau lebih dapat berhadap-hadapan secara fisik. Metode wawancara mendalam ini diharapkan akan memperoleh data primer yang berkaitan dengan penelitian ini dan mendapat gambaran yang lebih jelas guna mempermudah dan menganalisis data selanjutnya. Wawancara mendalam akan dilakukan dengan pedoman wawancara, hal ini dimaksudkan agar pertanyaan yang diajukan oleh peneliti dapat terarah, tanpa mengurangi kebebasan dalam mengembang-kan pertanyaan. Wawancara mendalam dengan masyarakat yang menjadi sampel dalam penelitian bersama pelaksana PTSL di Kecamatan Tumpaan Kabupaten Minahasa Selatan serta masyarakat yang terdaftar sebagai peserta PTSL tahun 2017.

4. Dokumentasi

Dokumentasi adalah teknik pengumpulan data atau dokumen yang berhubungan dengan penelitian dengan mempelajari catatan-catatan mengenai data pribadi responden.

\section{Metode Analisis Data}

Penelitian ini menggunakan teknik analisis data deskriptif kualitatif. Teknik analisis ini merupakan teknik analisis data dengan mengungkapkan kejadian/fakta, dan keadaan yang terjadi saat penelitian berlangsung dengan menyajikan data sesuai dengan kondisi eksisting. (Badjuri dan Yuwono, 2002).

Data dianalisis dengan model siklus interaktif, proses ini dilakukan selama proses penelitian ditempuh melalui serangkaian proses, pengumpulan, reduksi, penyajian, dan verifikasi data. Reduksi data dimaksudkan sebagai langkah atau proses mengurangi atau membuang data yang tidak perlu, penyederhanaan, memfokuskan, atau menyeleksi untuk menajamkan data yang diperoleh. Berdasarkan sajian data tersebut, peneliti terlebih dahulu melihat hubungan satu dengan yang lain dalam kesatuan bahasan lalu menarik kesimpulan. Selanjutnya peneliti melakukan interpretasi dan memberi makna terhadap fenomena/gejala yang ditemukan (Miles dan Huberman, 1984).

Pengukuran evaluasi kegiatan Pendaftaran Tanah Sistematis Lengkap (PTSL) di Kecamatan Tumpaan Kabupaten Minahasa Selatan peneliti menggunakan Tabel 1 sebagai indikator evaluasi kegiatan. 


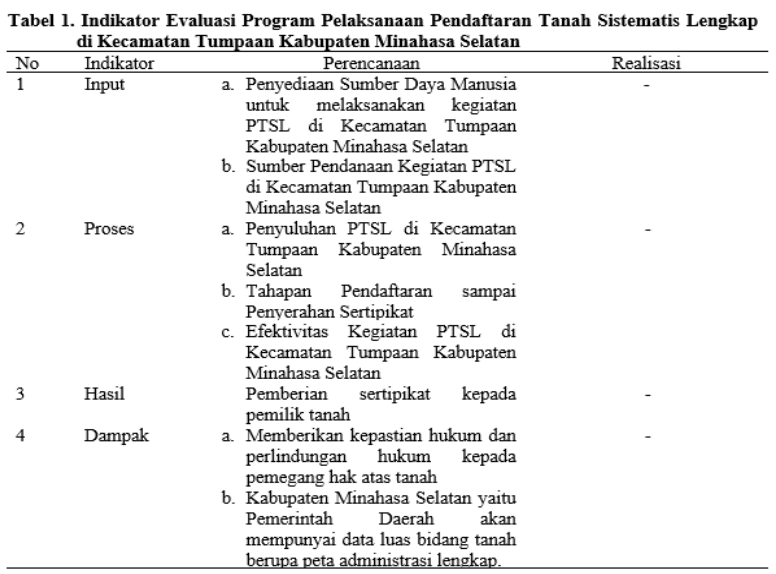

Tabel 1 menunjukkan uraian indikator evaluasi yang bersangkutan dengan situasi yang sementara terjadi, perilaku yang terjadi di dalam suatu masyarakat, pertentangan antara dua hal yang terjadi atau lebih, hubungan antar beberapa variabel yang ada, juga perbedaan antar fakta serta pengaruhnya terhadap suatu kondisi dalam hal pelaksanaan Pendaftaran Tanah Sistematis Lengkap di Kecamatan Tumpaan Kabupaten Minahasa Selatan.

\section{HASIL DAN PEMBAHASAN}

\section{Deskripsi Wilayah Penelitian}

\section{Letak Geografis, Administratif, dan Kondisi Fisik}

Kabupaten Minahasa Selatan adalah salah satu Kabupaten di Provinsi Sulawesi Utara yang terletak diantara $0^{\circ}, 47^{\prime}-1^{\circ} 24^{\prime}$ lintang utara dan $124^{\circ} 45^{\prime}$ bujur timur. Ibukota Kabupaten Minahasa Selatan adalah Kota Amurang yang berjarak $\pm 64 \mathrm{~km}$ dari Kota Manado. Kabupaten Minahasa Selatan terbentuk berdasarkan Undang-Undang Nomor 10 Tahun 2003 tentang pembentukan Kabupaten Minahasa Selatan dan Kota Tomohon di Provinsi Sulawesi Utara.

Luas Kabupaten Minahasa Selatan adalah 1.484,47 km² terdiri dari 17 Kecamatan dengan 177 desa. Sebagian besar wilayah Minahasa Selatan memiliki topografi bergunung-gunung yang membentang dari utara ke selatan. Kecamatan Tumpaan adalah salah satu kecamatan di Kabupaten Minahasa Selatan, berjarak sekitar 50 km dari Kota Manado, Ibu Kota Propinsi Sulawesi Utara. Kecamatan Tumpaan memiliki topografi wilayah hamparan dengan ketinggian lebih dari 14 meter dari permukaan laut. Batas administrasi Kecamatan Tumpaan adalah sebagai berikut:

$$
\begin{aligned}
& \text { Batas Utara : Kabupaten Minahasa } \\
& \text { Batas Barat : Kecamatan Tatapaan dan Laut } \\
& \text { Sulawesi } \\
& \text { Batas Selatan : Kecamatan Amurang Timur } \\
& \text { Batas Timur : Kecamatan Suluun Tareran }
\end{aligned}
$$

\begin{tabular}{|c|c|c|c|c|}
\hline No & Desa/Kelurahan & Penduduk & Luas Area & Kepadatan \\
\hline 1. & Tumpaan & 1.673 & 3,75 & 446 \\
\hline 2. & Tumpaan Satu & 2.245 & 2,00 & 1.123 \\
\hline 3. & Matani & 1.341 & 1,78 & 753 \\
\hline 4. & Popontolen & 1.770 & 4,50 & 393 \\
\hline 5. & Lelema & 1.773 & 27,05 & 66 \\
\hline 6. & Tangkuney & 1.284 & 25,00 & 51 \\
\hline 7. & Munte & 1.875 & 128,50 & 15 \\
\hline 8. & Tumpaan Baru & 1.728 & 3,00 & 576 \\
\hline 9. & Tumpaan Dua & 1.978 & 3,27 & 605 \\
\hline 10. & Matani Satu & 2.103 & 16,00 & 131 \\
\hline & Jumlah/Total & 17.770 & 214,85 & 83 \\
\hline
\end{tabular}

Tabel 2. Jumlah Penduduk, Luas Wilayah dan Kepadatan

Tabel 2 menunjukkan bahwa Kecamatan Tumpaan dibagi ke dalam 10 kelurahan/desa. Kecamatan Tumpaan memiliki Penduduk sebanyak 17.770 jiwa Luas, dengan jumlah penduduk terbanyak di Desa Tumpaan Satu berkisar 2.245 jiwa dan yang sedikit di Desa Tangkuney berkisar 1.284 jiwa. Luas Wilayah $214,85 \mathrm{Km}^{2}$, dengan Desa terluas Desa Munte $\left(128,5 \mathrm{Km}^{2}\right)$ dan Desa dengan luas wilayah terkecil adalah Desa Matani $\left(1,78 \mathrm{Km}^{2}\right)$. Kepadatan penduduk keseluruhan mencapai $83 \mathrm{jiwa} / \mathrm{km}^{2}$.

\section{Pelaksanaan Pendaftaran Tanah Sistematis Lengkap (PTSL) di Kecamatan Tumpaan Kabupaten Minahasa Selatan}

Kecamatan Tumpaan Kabupaten Minahasa Selatan merupakan salah satu lokasi yang telah ditetapkan sebagai lokasi percepatan pelaksanaan pendaftaran tanah sistematis lengkap pada tahun anggaran 2017 di Kabupaten Minahasa selatan berdasarkan Surat Keputusan Kepala Kantor Pertanahan Kabupaten Minahasa Selatan Nomor 35/KEP.71.300/V/2017. Pendaftaran Tanah Sistematis Lengkap adalah kegiatan pendaftaran tanah untuk pertama kali yang dilakukan secara serentak yang meliputi semua obyek pendaftaran tanah yang belum di daftar dalam satu wilayah desa atau kelurahan atau nama lainnya yang setingkat dengan itu. Pendaftaran Tanah Sistematis Lengkap merupakan program pemerintah yang mengacu pada Peraturan Menteri Agraria dan Tata Ruang/Kepala Badan Pertanahan Nasional Republik Indonesia Nomor 1 Tahun 2017 tentang Perubahan Atas Peraturan Menteri Agraria dan Tata Ruang/Kepala Badan Pertanahan Nasional Nomor 35 Tahun 2016 tentang Percepatan Pelaksanaan Pendaftaran Tanah Sistematis Lengkap.

Berdasarkan data yang diperoleh di Kantor Pertanahan Kabupaten Minahasa Selatan pada tahun 2017 dibentuk tim yang disebut Panitia Ajudikasi untuk Pelaksanaan Pendaftaran Tanah Sistematis Lengkap. Kepala Kantor Pertanahan dalam rangka pendaftaran tanah sistematik lengkap dibantu oleh Panitia Ajudikasi tersebut. Penetapan mekanisme rincian tugas Panitia Ajudikasi merupakan hal yang penting dalam pelaksaanaan pendaftaran tanah sistematik guna terlaksananya proses pendaftaran tanah dengan baik. 
Penetapan fungsi, tugas, dan wewenang yang jelas sangat membantu anggota organisasi dalam melaksanakan kewajibannya, sehingga dapat terhindar dari perangkapan jabatan atau melebihi kewenangannya dalam bertindak.

1. Hasil Wawancara dan Observasi Pelaksanaan PTSL di Kecamatan Tumpaan Kabupaten Minahasa Selatan.

a. Hasil Pelaksanaan Wawancara Terhadap Responden

Hasil wawancara dengan masyarakat peserta terdaftar PTSL diperoleh kesimpulan bahwa masyarakat menyambut baik pelaksanaan kegiatan PTSL yang diselenggarakan di Kecamatan Tumpaan, Kabupaten Minahasa Selatan. Beberapa masyarakat yang menjadi responden mengatakan bahwa pelaksanaan kegiatan PTSL memberikan keuntungan terhadap masyarakat yang terdaftar dalam program PTSL karena dengan kegiatan ini responden secara langsung sudah memiliki sertipikat sebagai alas hak dan kepastian hukum serta keterangan mengenai tanda batas kepemilikan tanah.

Hasil wawancara terhadap peserta kegiatan PTSL di Kecamatan Tumpaan Kabupaten Minahasa Selatan menunjukkan terdapat sebanyak 18 responden atau $85,71 \%$ yang menganggap pelaksanaan kegiatan PTSL berada pada kategori baik sedangkan 3 orang atau sebesar 14,28\% menganggap sangat baik. Pelaksanaan kegiatan PTSL di Kecamatan Tumpaan Kabupaten Minahasa Selatan sudah didahului dengan kegiatan penyuluhan dengan tujuan mengedukasi masyarakat terkait pelaksanaan kegiatan PTSL di daerah mereka. Respon terhadap penyuluhan yang dilaksanakan oleh Kantor Badan Pertanahan Nasional Kabupaten Minahasa Selatan terdapat 2 orang atau 9,52\% responden yang mengatakan belum paham dengan penyuluhan yang disampaikan, sedangkan 19 orang reponden atau sebanyak 90,47\% mengatakan paham dengan penyuluhan tentang PTSL yang disampaikan. Data yang diperoleh dari masyarakat peserta kegiatan PTSL sejumlah 21 orang atau $100 \%$ mengatakan bahwa tanah yang didaftarkan merupakan tanah milik mereka dan bukan merupakan tanah garapan. Terdapat 7 orang atau $33,33 \%$ dari total responden yang yang merasa sangat menguntungkan tentang adanya program PTSL ini sedangkan 14 orang atau $66,66 \%$ responden merasa program PTSL menguntukan bagi mereka. 10 orang responden atau $47,61 \%$ dari total responden tidak mengalami kesulitan dalam proses pengurusan PTSL, sedangkan 11 orang responden atau sebanyak 52,38\% mendapatkan kesulitan dimana kelengkapan berkas dan data yang mereka miliki tidak memenuhi syarat. Jumlah tanah di Kecamatan Tumpaan Kabupaten Minahasa Selatan masih banyak yang belum memiliki alas hak atau dasar hukum yang kuat yaitu sertipikat, pernyataan ini sesuai dengan apa yang disampaikan oleh seluruh responden yang berjumlah 21 atau $100 \%$ dari total responden peserta kegiatan PTSL. b. Hasil Pelaksanaan Wawancara Terhadap Panitia Pelaksana PTSL.

Berdasarkan hasil wawancara dengan pelaksana PTSL, kendala yang sering terjadi dalam pelaksanaan PTSL yaitu ketersediaan dokumen dari masyarakat, dan masalah dengan tanda batas serta bukti kepemilikan yang tidak jelas mengenai asal usul tanah tersebut. Hasil wawancara terhadap pelaksana PTSL dapat dilihat Tabel 3.

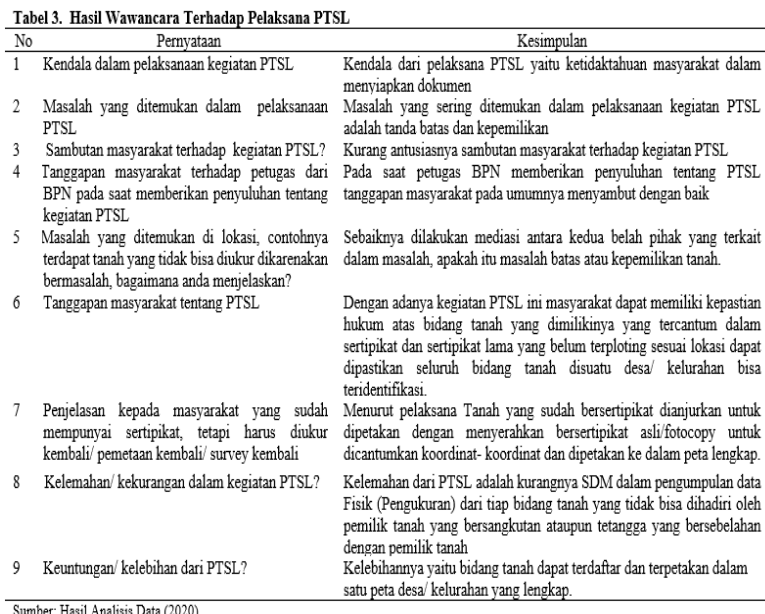

Faktor penentu keberhasilan kegiatan pendaftaran tanah yaitu mencakup kesiapan SDM, regulasi, infrastruktur, anggaran dan sinergisme kelembagaan, sedangkan indikator keberhasilan pelaksanaan PTSL adalah tercapainya hasil pelaksanaan sesuai sasaran/target yang ditetapkan berupa kuantitas pada satuan kantor pertanahan tersebut dengan tepat waktu sesuai anggaran dan berkualitas. Hasil wawancara terhadap pelaksana PTSL dapat dilihat Tabel 4.

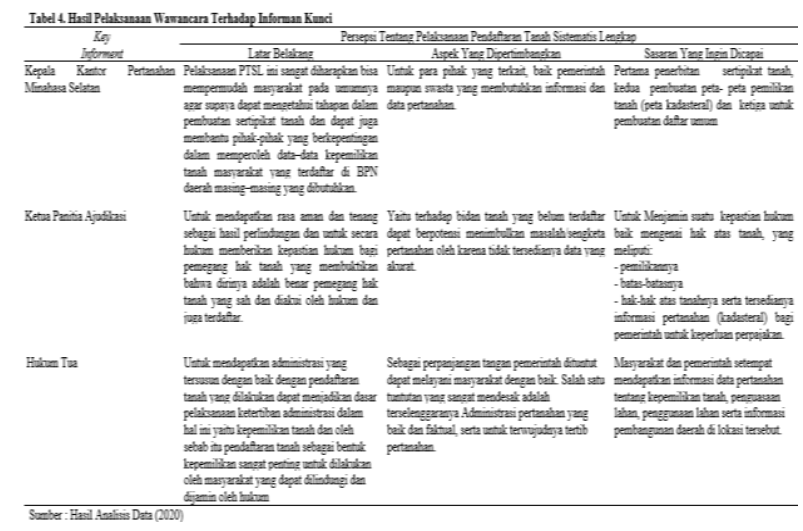

Pelaksanaan Kegiatan Pendaftaran Tanah Sistematis Lengkap di Kabupaten Minahasa Selatan tahun 2017 salah satunya berlokasi di Kecamatan Tumpaan. Pelaksanaan kegiatan ini dimulai dengan persiapan oleh Kantor Petanahan Kabupaten Minahasa Selatan yang didalamnya terdapat kegiatan sosialisasi, penetapan lokasi, perencanaan tenaga panitia, dan pembentukan panitia. Proses selanjutnya dilakukan 
sesuai dengan Peraturan Menteri Nomor 35 Tahun 2016 dan Petunjuk Teknis Pengukuran dan Pemetaan Bidang Tanah Sistem Secara Lengkap Tahun 2016. Berdasarkan hasil Observasi di lapangan, pelaksanaan Kegiatan PTSL di Kecamatan Tumpaan Kabupaten Minahasa Selatan dilakukan dalam tahapan sebagai berikut:

1) Persiapan

a. Sosialisasi

Kantor Pertanahan Kabupaten Minahasa Selatan memberikan informasi akan dilaksanakannya Pendaftaran Tanah Sistematis Lengkap kepada masyarakat secara langsung. Kegiatan ini dimaksudkan agar masyarakat setempat mengetahui bahwa akan ada kegiatan PTSL yang akan diselenggarakan di lokasi tempat tinggal mereka.

b. Penetapan Lokasi dan Jumlah Bidang

Kantor Pertanahan Kabupaten Minahasa dalam hal ini Kepala Kantor Pertanahan menetapkan beberapa Kecamatan yang akan menjadi lokasi untuk dilaksakanannya kegiatan PTSL Tahun 2017 termasuk di dalamnya Kecamatan Tumpaan. Lokasi ditetapkan dengan melihat ketersediaan peta kerja, ketersediaan dan kemampuan optimal panitia dan satgas.

c. Perencanaan tenaga panitia dan satgas yuridis

Susunan panitia dalam pendaftaran tanah sistematis lengkap di Kecamatan Tumpaan terdiri dari panitia ajudikasi percepatan berjumlah 6 orang pegawai BPN, satuan tugas fisik percepatan berjumlah 3 orang, satuan tugas yuridis berjumlah 11 orang, dan satuan tugas pengelola berjumlah 11 orang.

d. Pembentukan Panitia Ajudikasi Percepatan

Pembentukan kepanitiaan maupun satuan tugas yang ada ditetapkan sesuai dengan Surat Keputusan Kepala Kantor Pertanahan Kabupaten Minahasa Selatan Tahun 2017 Nomor 45/KEP.71.300/X/2017 sebagaimana Peraturan Menteri Agraria dan Tata Ruang/Kepala Badan Pertanahan Nasional Nomor 1 Tahun 2017 lampiran II.

2) Penyuluhan

Penyuluhan tentang Pendaftaran Tanah Sistematis Lengkap di Kecamatan Tumpaan Kabupaten Minahasa Selatan dilakukan pada bulan kedua sejak persiapan dilaksanakan atau diterbitkannya Surat Keputusan yang pertama. Penyuluhan yang disampaikan ke masyarakat berupa tahapan kegiatan pendaftaran sistematis lengkap. Dokumen yuridis yang perlu disiapkan, jadwal pengumpulan data yuridis, kluster hasil akhir kegiatan ajudikasi percepatan, dan materi mengenai program PTSL yang disampaikan kepada masyarakat peserta kegiatan PTSL. Dengan diadakannya kegiatan penyuluhan PTSL tersebut kepada masyarakat Kecamatan Tumpaan Kabupaten Minahasa Selatan diharapkan akan meningkatkan pemahaman serta kesadaran masyarakat mengenai kegiatan Pendaftaran Tanah.

\section{3) Pengumpulan data yuridis}

Pengumpulan data yuridis dilakukan oleh satuan tugas yuridis percepatan pendaftaran tanah sistematis lengkap Kantor Pertanahan Kabupaten Minahasa Selatan. Inventarisasi/Pengumpulan data yuridis dilakukan dengan formulir-formulir isian inventarisasi dan identifikasi peserta pendaftaran tanah sistematis lengkap dan dilakukan bersamaan dengan pemetaan partisipatif yang dilakukan oleh satgas fisik.

4) Pengukuran Bidang Tanah

Pengukuran dilakukan oleh tim satgas fisik yang terdiri dari petugas ukur dari pihak ketiga maupun dari petugas ukur kantor pertanahan Kabupaten Minahasa Selatan. Pengukuran bidang tanah yang dilakukan dengan menggunakan Peta Dasar Pendaftaran, Data mentah Foto Udara dan Alat Ukur TS (Total Station) dan GPS Geodetik. Pengukuran Bidang Tanah dilakukan bersamaan dengan pengumpulan data yuridis oleh panitia dan satgas yuridis Kantor Pertanahan Kabupaten Minahasa Selatan.

5) Pengolahan Data Yuridis dan Pembuktian Hak

Pengolahan data untuk kegiatan PTSL yang dilakukan di Kantor Pertanahan Kabupaten Minahasa Selatan, yaitu melalui aplikasi Komputerisasi Kegiatan Pertanahan (KKP). Mulai dari pendaftaran, proses data sampai pengumuman hasil akhir pengesahan dari Pengumuman. Data Yuridis yang terkumpul dianalisa oleh Panitia Ajudikasi Percepatan, menyangkut data kepemilikan yang menunjukan hubungan hukum antara peserta PTSL dengan tanah obyek PTSL.

6) Pemeriksaan Tanah

Pemeriksaan tanah dilakukan untuk memastikan keterangan yang tertuang didalam data yuridis sesuai dengan keadaan dilapangan. Dilakukan dengan cara menggali informasi yang meliputi kesesuaiannama dan profesipeserta. Membandingkan keterangan yang tertera didalam formulirisian inventarisasi dan dokumen/data yuridis dengan kesesuain dengan kondisi penguasaan, penggunaan tanah tersebut dilapangan, serta kesesuaian letak, batas dan luas yang tertuang dalam data fisik (peta bidangtanah) dengan kenyataan di lapangan.

7) Pengumuman

Hasil pemeriksaan tanah yang dilakukan kemudian dibukukan atau dapat dilakukan penerbitan Sertipikat Hak Atas Tanah satu bidang tanah. Data yang sudah ada diumumkan dalam papan pengumuman selama 14 hari dengan tujuan untuk diketahui oleh masyarakat peserta PTSL dan memberi kesempatan kepada pihak-pihak yang berkepentingan untuk mengajukan keberatan.

8) Pengesahan

Hasil dari pengumuman disahkan dalam Berita Acara Hasil Pengumuman oleh Panitia Ajudikasi Percepatan Pendaftaran Tanah Sistematis Lengkap Kantor Pertanahan Kabupaten Minahasa Selatan. 
9) Penerbitan Surat Keputusan Penetapan Hak dan Keputusan Penegasan/Pengakuan Hak

Penandatangan Surat Keputusan Penetapan Hak dan Keputusan/ penegasan/ pemberian hak dilakukan oleh Ketua Panitia Ajudikasi setelah pengumuman hasil dari proses data fisik dan yuridis. Dalam rangka penerbitan Surat Keputusan Pemberian Hak, bagi masyarakat yang mampu membayar BPHTB, bukti pembayaran dibawa pada saat pendaftaran hak. Panitia Ajudikasi Percepatan Bidang Yuridis menyediakan/mencetak Sertipikat Hak Atas Tanah, Kepala Kantor Pertanahan menandatangani Sertipikat Hak Atas Tanah atau dapat mendelegasikan kewenangan penandatanganan Sertipikat kepada Ketua Panitia Ajudikasi Pertanahan. Penerbitan/Penyelesaian akhir Sertipikat dilakukan oleh Petugas Kantor Pertanahan.

10) Pembukuan Hak

Pembukuan Hak disiapkan oleh Panitia Ajudikasi Percepatan Bidang Yuridis Kantor Pertanahan Kabupaten Minahasa, kemudian dicetak dan diserahkan kepada Ketua Panitia Ajudikasi Percepatan untuk dilakukan penandatanganan buku tanah.

11) Pengelolaan Warkah/Dokumen

Pengelolaan Warkah atau dokumen dilakukan oleh Panitia Ajudikasi Pendaftaran Tanah Sistematis Lengkap Kantor Pertanahan Kabupaten Minahasa Selatan. Panitia Ajudikasi mendokumentasikan seluruh warkah/dokumen data fisik maupun yuridis yang ada untuk kepentingan pelaporan kegiatan PTSL yangdiselenggarakan oleh Kantor Pertanahan Kabupaten Minahasa Selatan.

12) Pelaporan

Sesuai dengan Petunjuk Teknis yang diberikan, bagian akhir dari kegiatan Pendaftaran Tanah Sistematis Lengkap adalah penyusunan laporan hasil pelaksanaan kegiatan PTSL. Kegiatan Pelaporan disusun oleh panitia ajudikasi percepatan, kemudian dilakukan dilakukan pelaporan secara berjenjang dan berkala dari Kantor Pertanahan Kabupaten Minahasa Selatan kepada kepala kantor wilayah selanjutnya kepada kementerian agraria dan tata ruang/badan pertanahan nasional, dengan menggunakan SKMPP.

2. Manfaat Pendaftaran Tanah Sistematik Lengkap di

Kecamatan Tumpaan Kabupaten Minahasa Selatan.

Dalam upaya tertib hukum pendaftaran tanah maka diselenggarakan kegiatan PTSL oleh Pemerintah dalam hal ini Kantor Agraria dan Tata Ruang/Badan Pertanahan Nasional Kabupaten Minahasa Selatan melalui pelaksanaan PTSL. Kegiatan PTSL bermaksud untuk memberikan pelayanan pendaftaran tanah dengan proses yang sederhana, mudah, cepat, dan murah.

Sertipikat tanah memuat informasi tentang data fisik dan data yuridis sebagai rekonstruksi terhadap subyek dan obyek hak atas tanah. Sertipikat menampung data yang akurat dan faktual yang merupakan jaminan kepastian hukum. Dengan demikian jika setiap bidang tanah sudah didaftar haknya dengan disertai sertipikat tanah sebagai bukti sah kepemilikannya, niscaya perebutan dan sengketa tanah dapat dihilangkan atau setidaknya diminimalisir.

a. Tertib Penggunaan Tanah

Tertib penggunaan tanah merupakan kondisi dimana setiap bidang tanah telah digunakan secara optimal, serasi dan seimbang sesuai dengan potensi, guna berbagai kegiatan kehidupan dan penghidupan. Selain dari itu tidak terdapat benturan kepentingan antar sektor penggunaan tanah. Fungsi tanah dapat benarbenar diupayakan agar bermanfaat untuk kemakmuran rakyat dengan cara setiap individu, badan hukum, atau instansi yang mempunyai hubungan hukum dengan tanah wajib menggunakan tanahnya, memelihara, serta mencegah terjadinya kerusakan, sehingga tanah lebih berdaya guna dan berhasil guna serta bermanfaat bagi kesejahteraan masyarakat. Pelaksanaan Pendaftaran Tanah Sistematis Lengkap di Kecamatan Tumpaan Kabupaten Minahasa Selatan difokuskan pada daerahdaerah penduduk perdesaan atau kelurahan. Hal ini dilakukan berdasarkan pertimbanngan sebagian besar tanah pada wilayah tersebut belum terdaftar. Selain dari itu kondisi perekonomian masyarakat setempat termasuk kategori berpenghasilan menengah ke bawah. Dengan dilaksanakannya pendaftaran tanah sistematik berangsur-angsur menuju kearah perbaikan. Hal ini ditanda dengan semakin yakinnya masyarakat setempat bahwa tanah yang mereka tempati sudah mempunyai hak dan sudah berkekuatan hukum yang sah. Dari persepsi yang demikian warga menjadi lebih peduli terhadap lingkungannya. Keadaan ini terlihat dengan munculnya semangat warga untuk membangun rumahnya menjadi lebih rapih dan disertai fasilitas perbaikan got, pembuatan bak sampah, serta pembuatan taman sederhana dibeberapa tempat umum.

b. Tertib Pemeliharaan Tanah dan Lingkungan Hidup

Saat ini terdapat banyak orang atau badan hukum yang mempunyai atau menguasai tanah yang tidak memperhatikan dan melakukan usaha-usaha untuk mencegah kerusakan-kerusakan dan kehilangan kesuburan tanah. Pada lain pihak, kepadatan penduduk yang melampaui batas tampung wilayah, telah mendorong untuk mempergunakan tanah tanpa mengindahkan batas kemampuan keadaan tanah dan faktor lingkungan hidup. Oleh karena itu, manfaat yang diperoleh dari tertib pemeliharaan tanah dan lingkungan hidup merupakan keadaan dimana penanganan bidang pertanahan telah dapat menunjang kelestarian hidup, adanya pemberian hak atas tanah dan pengarahan penggunaan telah dapat menunjang terwujudnya pembangunan yang berkelanjutan dan bernuansa lingkungan, adanya kemauan semua pihak yang mempunyai hubungan hukum dengan tanah melaksanakan kewajiban sehubungan dengan pemeliharaan tanah tersebut. 
Badan Pertanahan Nasional bertugas untuk mengelola dan mengembangkan administrasi pertanahan yang meliputi Pengaturan Penggunaan, Penguasaan, Pemilikan dan Pengelolaan Tanah (P4T), penguasaan hak-hak atas tanah, pengukuran dan pendaftaran tanah dan lain-lain yang berkaitan dengan masalah pertanahan, sehingga Badan Pertanahan Nasional sangat berperan aktif dalam mewujudkan penggunaan tanah untuk sebesar-besar kemakmuran rakyat dengan melaksanakan fungsinya di bidang pertanahan sebagai lembaga non Departemen pembantu Presiden. Tanah merupakan sarana untuk melaksanakan pembangunan. Kedudukan tanah yang penting ini kadang tidak diimbangi dengan usaha untuk mengatasi berbagai permasalahan yang timbul dalam bidang pertanahan. Fakta memperlihatkan bahwa keresahan di bidang pertanahan mendatangkan dampak negatif di bidang sosial, politik dan ekonomi. Pendaftaran tanah merupakan kewajiban Pemerintah dalam hal ini Kementerian ATR/BPN.

Selain kendala dalam penyiapan dokumen terkait pembuktian penguasaan dan kepemilikan tanah, kendala lain dalam pelaksanaan kegiatan PTSL di Kecamatan Tumpaan Kabupaten Minahasa Selatan adalah saat pengukuran pemilik tanah tidak berada di lokasi terkait, hal ini banyak terjadi diakibatkan pemilik tanah banyak yang tinggal di luar kota, hal tersebut mempersulit petugas dalam proses pendataan. Keberadaan pemilik tanah penting untuk pendataan syarat-syarat yang harus dipenuhi oleh peserta dalam Kegiatan Pelaksanaan PTSL.

Berdasarkan wawancara yang sudah dilakukan, peneliti menggunakan tabel indikator untuk memberikan evaluasi secara restospektif ( $E x$ post) terhadap Program Pelaksanaan Pendaftaran Tanah Sistematis Lengkap yang sudah dilaksanakan di Kecamatan Tumpaan Kabupaten Minahasa Selatan Tahun 2017. Proses, hasil, dan dampak dari kegiatan yang sudah dilakukan dapat dilihat pada Tabel 5 .

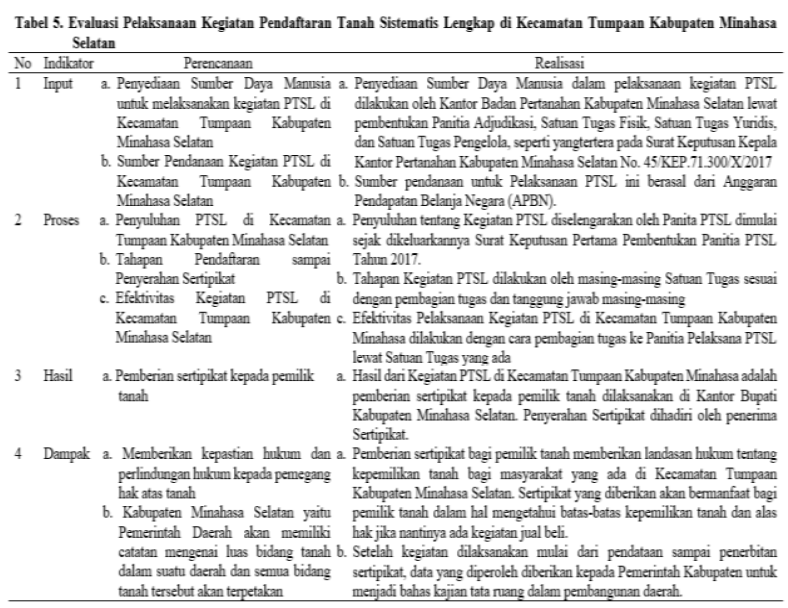

Kantor pertanahan Kabupaten Minahasa Selatan berupaya melaksanakan kebijakan pertanahan dalam rangka terwujudnya kepastian hukum bagi masyarakat pemegang hak atas tanah dan untuk terlaksananya Sapta Tertib Pertanahan berdasarkan Keputusan Kepala Badan Pertanahan Nasional Republik Indonesia Nomor 277 Tahun 2012 tentang Sapta Tertib Pertanahan. Kegiatan pendaftaran tanah sistematis lengkap di Kecamatan Tumpaan Kabupaten Minahasa Selatan mengacu pada Peraturan Menteri Negara Agraria/Kepala Badan Pertanahan Nasional Nomor 35 Tahun 2016 tentang percepatan pelaksanaan Pendaftaran Tanah Sistematis Lengkap (PTSL), dalam rangka memberikan jaminan kepastian hukum hak atas tanah sebagai bukti hak kepemilikan yang diamanatkan dalam pasal 19 Undang-undang Nomor 5 Tahun 1960 tentang Peraturan Dasar Pokok-pokok Agraria, pemerintah dalam hal ini Kementerian Agrarian/Badan Pertanahan Nasional berkewajiban menyelenggarakan pendaftaran tanah diseluruh wilayah Republik Indonesia. Salah satu cara yang ditempuh Kementerian Agraria dan Tata Ruang untuk mengejar presentase tanah terdaftar yang masih dibawah 50\% adalah melalui kegiatan percepatan pelaksanaan pendaftaran tanah sistematis lengkap sebagaimana diatur dalam Peraturan Menteri Agraria dan Tata Ruang/ Badan Pertanahan Nasional Nomor 35 Tahun 2016 Tentang percepatan Pelaksanaan Pendaftaran Tanah Sistematis Lengkap.

Hasil wawancara terhadap pelaksana PTSL dalam hal ini pegawai di Kantor Pertanahan Kabupaten Minahasa Selatan, menyatakan bahwa masyarakat tidak siap dan tidak mampu untuk menyiapkan dokumen kepemilikan tanah mereka dan masyarakat tidak memiliki tanda batas terhadap tanah yang mereka miliki sehingga sering menjadi kendala dalam kegiatan pendaftaran tanah sistematis lengkap. Kurangnya pengetahuan masyarakat tentang Pelaksanaan Pendaftaran Tanah Sistematis Lengkap termasuk menyiapkan kelengkapan berkas pemilikan dan memasang tanda batas tanah sehingga menyebabkan masyarakat kurang antusias. Dalam kegiatan Pendaftaran Tanah Sistematis Lengkap masyarakat yang sudah memiliki sertipikat tanah wajib untuk mendaftarakan sertipikatnya untuk dipetakan dalam peta pendaftaran. Dari hasil wawancara ditemui masih ada tanah yang belum bersertipikat disekitar mereka yang sudah memiliki sertipikat sehingga dianjurkan untuk dipetakan agar mempermudah dalam pengurusan selanjutnya.

Berdasarkan hasil wawancara terdapat 18 peserta yang menyatakan bahwa mereka memahami tentang kegiatan pelaksanaan Pendaftaran Tanah Sistematis Lengkap pada saat Kantor Pertanahan Kabupaten Minahasa Selatan melakukan penyuluhan dan 3 peserta menyatakan kurang mengerti, dari keseluruhan jumlah peserta Pendaftaran Tanah Sistematis Lengkap yaitu sebanyak 21 peserta. Kegiatan pensertifikatan tanah melalui program Pendaftaran Tanah Sistematis Lengkap 
dikatakan masyarakat sangat membantu tetapi terdapat kendala dalam penyiapan dokumen kepemilikan tanah dan pemasangan tanda batas seperti yang diuraikan diatas. Peserta Tanah Sistematis Lengkap 9 responden menyatakan tidak menemukan kendala dalam menyiapkan kelengkapan berkas tanah dan 12 responden menyatakan memiliki kesulitan dalam melengkapi kelengkapan berkas kepemilikan tanah terutama berhubungan dengan status/kepemilikan tanah.

Kondisi yang ditemui dilapangan oleh pelaksana Pendaftaran Tanah Sistematis Lengkap yaitu masyarakat memiliki bukti kepemilikan tanah yang kurang jelas bahkan tidak ada bukti dan pada saat pengukuran pemilik tanah tidak berada dilokasi, serta tidak terpasang patok tanda batas tanah.

Semua tanah bisa didaftar untuk sertifikasi, tak terkecuali bidang tanah yang statusnya masih dalam sengketa. Semua bidang tanah yang masuk program PTSL akan disertipikat tentunya setelah statusnya sudah jelas (Peraturan Menteri Agraria dan Tata Ruang Nomor 35 Tahun 2016 tentang Percepatan Pelaksanaan Pendaftaran Tanah Sistematis Lengkap).

\section{KESIMPULAN DAN SARAN}

\section{Kesimpulan}

Kegiatan Pendaftaran Tanah Sistematis Lengkap di Kecamatan Tumpaan Kabupaten Minahasa Selatan telah berjalan sesuai dengan tahapan kegiatan. Terdapat sebanyak 18 atau $85,71 \%$ responden yang menganggap pelaksanaan kegiatan PTSL berada pada kategori baik sedangkan 3 orang atau sebesar 14,28\% menganggap sangat baik. Respon terhadap penyuluhan yang dilaksanakan oleh Kantor Badan Pertanahan Nasional Kabupaten Minahasa Selatan terdapat 2 orang atau 9,52\% responden yang mengatakan belum paham dengan penyuluhan yang disampaikan, sedangkan 19 orang reponden atau sebanyak 90,47\% mengatakan paham dengan penyuluhan tentang PTSL yang disampaikan. Terdapat 7 orang atau $33,33 \%$ dari total responden yang yang merasa sangat menguntungkan tentang adanya program PTSL ini sedangkan 14 orang atau $66,66 \%$ responden merasa program PTSL menguntukan bagi mereka. 10 orang responden atau $47,61 \%$ dari total responden tidak mengalami kesulitan dalam proses pengurusan PTSL, sedangkan 11 orang responden atau sebanyak $52,38 \%$ mendapatkan kesulitan dimana kelengkapan berkas dan data yang mereka miliki tidak memenuhi syarat.

Kendala dalam kegiatan Pendaftaran Tanah Sistematis Lengkap yaitu masyarakat memiliki bukti kepemilikan tanah yang kurang jelas seperti surat-surat kepemilikan tanah, riwayat tanah dari pemegang hak pertama sampai pemilik terakhir, bukti kepemilikan berdasarkan jual beli, hibah atau warisan, serta tanda batas atas tanah mereka dan pada saat pengukuran pemilik tanah tidak berada dilokasi, serta tidak terpasang patok tanda batas tanah dalam menyiapkan bukti kepemilikan tanah.

Manfaat metode atau program PTSL dalam pengembangan wilayah Kecamatan Tumpaan, Kabupaten Minahasa Selatan yaitu Pemerintah Daerah dapat mempunyai data luas bidang tanah dalam suatu daerah berupa peta administrasi lengkap, sehingga Pemerintah Daerah dapat melakukan perencanaan pengembangan wilayah berdasarkan informasi tata ruang yang tersedia.

\section{Saran}

Saran-saran yang dapat diberikan dari hasil penelitian ini adalah:

1. Untuk Kantor Pertanahan Kabupaten Minahasa Selatan disarankan bisa menambah tenaga SDM yang ada terutama untuk tenaga pengukuran di lapangan.

2. Kepada masyarakat pemilik tanah yang tidak atau belum memasang tanda/patok batas tanah disarankan untuk memasang patok yang disaksikan tetangga batasnya.

3. Kegiatan Pendaftaran Tanah Sistematis Lengkap perlu diadakan secara terus menerus dan berkelanjutan di seluruh wilayah desa/kelurahan sampai semua bidang tanah terpetakan secara lengkap agar terciptanya tertib pertanahan di seluruh wilayah Republik Indonesia.

\section{DAFTAR PUSTAKA}

Anonim. Petunjuk Teknis Pendaftaran Tanah Sistematis Lengkap bidang yuridis 2017.

Anonim. Undang-Undang Nomor 5 tahun 1960 Tentang Peraturan Dasar Pokok-Pokok Agraria dan Penjelasannya.

Badjuri, Abdulkahar \& Yuwono, Teguh, 2002, Kebijakan Publik Konsep \& Strategi, Undip Press, Semarang.

Creswell, John. W., 2002. Reseacrh Design: Qualitative and Quantitative Approach. Terjemahan: Nur Khabibah. Jakarta: KIK Press.

Miles. M. B. \& Huberman, A. M. 1984. Qualitative Data Analysis, A Sourcebook of New Methods. London, New Delhi: Sage Publications, Beverly Hills.

Peraturan Menteri Agraria dan Tata Ruang/Badan Pertanahan Nasional Nomor 1Tahun 2017 tentang Perubahan atas Peraturan Menteri Agraria dan Tata Ruang/Kepala Badan Pertanahan Nasional Nomor 35 tahun 2016. 